\title{
HUBUNGAN ANTARA KOMPETENSI PEDAGOGIK DAN PROFESIONAL GURU PPL JURUSAN PENDIDIKAN TEKNIK INFORMATIKA TERHADAP MOTIVASI BELAJAR SISWA SMK SE-KOTA SINGARAJA
}

\author{
Dewa Ayu Putu Candra Santika ${ }^{1}$, I Gede Mahendra Darmawiguna ${ }^{2}$, \\ Gede Saindra Sanyadiputra ${ }^{3}$
}
1,2,3 Jurusan Pendidikan Teknik Informatika, Universitas Pendidikan Ganesha, Singaraja, Bali
e-mail: chandra.id87@gmail.com¹, mahendra.darmawiguna@undiksha.ac.id², gsandras@undiksha.ac.id ${ }^{3}$

\begin{abstract}
Abstrak
Penelitian ini bertujuan untuk mengetahui hubungan antara kompetensi pedagogik guru PPL Jurusan Pendidikan Teknik Informatika terhadap motivasi belajar siswa SMK se-Kota Singaraja, hubungan antara kompetensi profesional guru PPL Jurusan Pendidikan Teknik Informatika terhadap motivasi belajar siswa SMK se-Kota Singaraja, hubungan kompetensi pedagogik dan profesional guru PPL Jurusan Pendidikan Teknik Informatika terhadap motivasi belajar siswa SMK se-Kota Singaraja. Jenis penelitian ini merupakan penelitian korelasi. Penelitian dilakukan dengan metode ex post facto (dilakukan untuk meneliti peristiwa yang telah terjadi secara sistematik, kemudian peneliti mengamati kebelakang tentang faktor - faktor yang dapat menyebabkan timbulnya kajian tersebut). Data angket siswa dianalisis dengan melakukan uji prasyarat yang meliputi uji normalitas, uji homogenitas dan uji linieritas. Pengujian hipotesis menggunakan uji anova. Berdasarkan hasil penelitian menujukkan bahwa (1) terdapat pengaruh yang positif dan signifikan antara kompetensi pedagogik guru PPL Jurusan Pendidikan Teknik Informatika terhadap motivasi belajar siswa SMK se-Kota Singaraja, (2) terdapat pengaruh yang positif dan signifikan antara kompetensi profesional guru PPL Jurusan Pendidikan Teknik Informatika terhadap motivasi belajar siswa SMK se-Kota Singaraja, (3) terdapat pengaruh kompetensi pedagogik dan profesional guru PPL Jurusan Pendidikan Teknik Informatika terhadap motivasi belajar siswa SMK se-Kota Singaraja.
\end{abstract}

Kata kunci: kompetensi pedagogik, profesional, motivasi belajar siswa.

\begin{abstract}
This study aimed at knowing the correlation between pedagogic competency of PPL teacher of information engineering education department torward students motivation of SMK in Singaraja, the correlation of professional competency of PPL teacher of Information engineering education department forward students motivation of SMK in Singaraja, the correlation between pedagogic and professional competencies of PPL teacher of information engineering education department toward students motivation of SMK in Singaraja. This study was correlation study. This study was done by using ex post facto method (it is used to conduct a research about case that has been systematically, then the researcher doing a deep research about the factors the caused that study). Then the conducted data was analyzed to get normality, homogeneity and linierlity of the data. The hypothesis was examined by using ANOVA test. The result showed that (1) there was significant affect of pedgogic competency of PPL teacher of information engineering education department toward students motivation of SMK in Singaraja, (2) there was significant affect of professional competency of PPL teacher of information engineering education department toward students motivation of SMK in Singaraja, (3) there was
\end{abstract}


significant affect of pedagogic and professional competencies of PPL teacher of information engineering education department toward students motivation of SMK in Singaraja.

Keywords: Personality competency, social competency, student's motivation.

\section{PENDAHULUAN}

Universitas Pendidikan Ganesha (Undiksha) Singaraja, merupakan salah satu Universitas Negeri yang mencetak calon tenaga pendidik dan kependidikan. Jurusan Pendidikan Teknik Informatika salah satu jurusan yang mencetak tenaga pendidik. Sejalan dengan hal itu lembaga telah menetapkan Program Pengalaman Lapangan secara Real (PPL-Real) sebagai salah satu mata kuliah yang wajib dilaksanakan oleh seluruh mahasiswa calon tenaga pendidik. PPL-Real adalah akumulasi atau muara seluruh kurikulum pendidikan prajabatan mahasiswa calon guru, yang mencakup pelatihan mengajar maupun tugas - tugas kependidikan di luar mengajar secara terbimbing dan terpadu untuk memenuhi persyaratan pembentukan kompetensi keguruan [1]. Sebelum PPL dilaksanakan, tentunya ada sistem pembelajaran yang ditetapkan dan diterapkan oleh setiap jurusan di Undiksha yang terorganisasi. Sistem pembelajaran yang dimaksud adalah micro teaching yang merupakan micro teaching ini sangat penting sebagai upaya sebelum mahasiswa calon guru terjun kelapangan untuk melaksanakan praktek mengajar. Megingat pelaksanaan PPL-Real merupakan suatu sistem, maka keberhasilannya tidak hanya didukung oleh sistem pembelajaran micro teaching saja, keberadaan lembaga terkait di Universitas sangat diperlukan untuk menangani kegiatan PPL-Real tersebut. Undiksha memiliki Lembaga

Pengembangan Pengalaman Lapangan (LPPL) yaitu lembaga yang menangani dan mengatur segala pelatihan mengajar mahasiswa di lapangan. Melalui lembaga ini pembentukan kompetensi keguruan telah disiapkan sejak dini mulai dari proses pembelajaran bertahap terpadu berupa PPL-Awal dan rangkaian materi perkuliahan yang dilakukan dengan pendekatan kompetensi. PPL-Real yang dilakukan dengan sistem magang selama sekitar 3 bulan ( \pm 14 minggu) mahasiswa calon guru dari Undiksha diharapkan memiliki kompetensi dalam mengajar. Tujuan PPL-
Real secara umum untuk melatih mahasiswa calon guru agar memiliki kemampuan memperagakan kinerja dalam situasi nyata dapat menimba dan menyerap pengalaman secara langsung dan cermat tentang : lingkungan fisik, administratif, akademik, sosial - psikologis sekolah, penguasaan berbagai keterampilan dasar mengajar dalam KBM, penerapan berbagai kemampuan profesional keguruan dan pengembangan kompetensi pembelajaran bidang studi [2]. Keberadaan dan keberhasilan guru PPL di sekolah praktik akan menimbulkan persepsi siswa untuk lebih termotivasi dalam pembelajaran untuk meningkatkan dan membangkitkan semangat dan perhatian siswa untuk mengikuti pelajaran. Hal tersebut tidak terlepas dari kompetensi atau kemampuan yang dimiliki oleh setiap guru PPL dalam pembelajaran.

Kompetensi yaitu seperangkat kemampuan yang disertai dengan tindakan intelegen penuh tanggung jawab yang harus dimiliki seseorang sebagai syarat untuk dianggap mampu melaksanakan tugas - tugas dalam bidang pekerjaan tertentu [1]. Kompetensi guru mengacu pada kemampuan sesorang melaksanakan sesuatu, yang mana kemampuan itu diperoleh dari pelatihan atau pendidikan. Kompetensi juga menunjuk pada kinerja dan perbuatan rasional, karena mempunyai arah dan tujan. Guru yang memiliki kompetensi akan menjadi sosok berkarakter, dengan kata lain kompetensi itu akan menjadi salah satu karakter dari guru [3]. Menurut Lembaga Pengembangan Pengalaman Lapangan (LPPL) Undiksha, mahasiswa PPL diharapkan memiliki 4 kompetensi yaitu, kompetensi pedagogik berupa kemampuan mengelola proses belajar mengajar secara utuh untuk memperoleh hasil optimal. Kompetensi profesional berupa penguasaan dan pemahaman tentang bidang keilmuan yang menjadi bidang pilihannya, maupun bidang pendidikan dan pembelajaran, maupun bidang lainnya yang mendukung keahliannya. Kompetensi personal yang 
berkaitan dengan sikap kepribadian, minat, disiplin diri dalam mengemban tugas dan tanggung jawab sesuai dengan tuntunan etika seorang guru. Kompetensi sosial berupa kemampuan untuk membina lingkungan atau hubungan yang baik masyarakat sekolah maupun masyarakat luas.

Keempat kompetensi tersebut harus dimiliki oleh mahasiswa PPL agar menciptakan pembelajaran yang menyenangkan. Cara mahasiswa PPL menciptakan pembelajaran yang menyenangkan dikelas akan berpengaruh terhadap minat dan motivasi siswa dalam proses pembelajaran [1]. Persoalan motivasi ini diartikan sebagai suatu kondisi yang terjadi apabila sesorang melihat ciri ciri atau arti sementara situasi yang dihubungkan dengan keinginan - keinginan atau kebutuhannya sendiri. Oleh karena itu apa yang dilihat dan didapatkan seseorang sudah tentu akan membangkitkan minat yang menjadi motivasi sejauh apa yang dilihat itu mempunyai hubungan dengan kepentingannya. Hal ini menunjukkan bahwa motivasi kecendrungan seseorang terhadap sesorang, karena merasa ada kepentingan dengan sesuatu itu. Motivasi timbul tidak secara tiba - tiba melainkan timbul akibat dari partisipasi, pengalaman, dan kebiasaan waktu belajar. Hal ini sangat penting karena motivasi berkaitan dengan keempat kompetensi guru dalam pembelajaran karena jelas bahwa motivasi akan selalu berkaitan juga dengan kebutuhan atau keinginan. Oleh karena itu yang penting bagaimana menciptakan kondisi tertentu agar siswa itu selalu butuh dan ingin terus belajar.

$$
\text { Jurusan Pendidikan Teknik }
$$

Informatika salah satu jurusan yang mahasiswanya aktif terdaftar dan telah mengikuti kegiatan PPL-Real di SMK seKota Singaraja. Mahasiswa PPL yang ideal harus memiliki pengetahuan, sikap dan keterampilan untuk menunjang tercapainya kompetensi pedagogik, kompetensi profesional, kompetensi kepribadian, dan kompetensi sosial. Dari ke 4 (empat) kompetensi tersebut penulis membatasi hanya membahas kompetensi pedagogik dan professional. Layaknya seorang guru dengan kompetensi tersebut, maka semua sikap dan tingkah laku mahasiswa yang sedang melaksanakan PPL-Real, seharusnya mampu menjadi contoh dan teladan bagi siswa, sehingga siswa termotivasi dan serius untuk belajar dengan mahasiswa PPL.

Berdasarkan penelitian yang dilakukan oleh (Anggono, 2012) terdapat hubungan yang positif dan signifikan antara persepsi siswa tentang atraksi interpersonal guru, fasilitas belajar, dan lingkungan belajar terhadap motivasi belajar siswa kelas X. (Irawan, 2007). dalam penelitiannya menunjukkan bahwa ada hubungan positif antara persepsi terhadap kompetensi guru dengan motivasi berprestasi sisa kelas VII, hal ini berarti hipotesis dapat diterima. (Annisa, 2005) dalam penelitiannya membuktikan bahwa terdapat hubungan positif antara persepsi tentang kompetensi profesional guru matematika dengan motivasi belajar matematika pada siswa kelas I SMA Negeri 1 Medan.

Berdasarkan latar belakang tersebut, maka penulis tertarik untuk melakukan penelitian dengan judul "Hubungan Antara Kompetensi Pedagogik, Profesional Guru PPL Jurusan Pendidikan Informatika Terhadap Motivasi Belajar Siswa SMK seKota Singaraja".

\section{KAJIAN TEORI}

\section{A. Kompetensi Pedagogik}

$$
\text { Kompetensi pedagogik yaitu }
$$

kemampuan seorang guru dalam mengelola proses pembelajaran peserta didik. Selain itu kemampuan pedagogik juga ditunjukkan dalam membantu membimbing dan memimpin peserta didik Imam (Wahyudi, 2012). Menurut kompetensi pedagogik merupakan kemampuan yang berkenaan dengan pemahaman peserta didik dan pengelolaan pembelajaran yang mendidik dan dialogis. Secara substantif kompetensi ini mencakup kemampuan pemahaman terhadap peserta didik, perancangan, dan pemahaman peserta didik untuk mengaktualisasi berbagai potensi yang dimilikinya. kompetensi pedagogik adalah pemahaman guru terhadap anak didik, perencanaan, pelaksanaan pembelejaran, evaluasi hasil belajar, dan pengembangan anak didik untuk mengaktualisasi sebagai potensi yang dimilikinya [1]. Kompetensi pedagogik ini juga sering dimaknai sebagai 
kemampuan mengelola pembelajaran. Ini mencakup konsep kesiapan mengajar yang ditunjukkan oleh penguasaan pengetahuan dan keterampilan mengajar. Mengajar merupakan sifatnya komplek dan multidimensional.

Dalam Standar Nasional Pendidikan, penjelasan Pasal 33 butir a dikemukakan bahwa kompetensi pedagogik adalah kemampuan mengelola pembelajaran peserta didik yang meliputi pemahaman terhadap peserta didik, perancangan dan pelaksanaan pembelajaran, evaluasi hasil belajar, dan pengembangan peserta didik untuk mengaktualisasikan berbagai potensi yang dimilikinya.

\section{Kemampuan Mengelola \\ Pembelajaran}

Dalam hal ini guru harus memahami bahwa peserta didik bukanlah "celengan" dan guru adalah "penabung". Guru harus dapat menciptakan pembelajaran yang dialogis dan bermakna. Kemampuan guru dalam mengelola pembelajaran sangat penting untuk diperhatikan karena menyangkut keberhasilan proses pembelajaran itu sendiri. Secara operasional kemampuan mengelola pembelajaran menyangkut fungsi perencanaan dan pelaksanaan.
a) Perencanaan
menyangkut

penetapan tujuan, kompetensi, serta memperkirakan cara mencapainya.

b) Pelaksanaan atau sering disebut implementasi adalah proses yang memberika kepastian bahwa belajar mengajar telah memiliki sumber daya manusia dan sarana prasarana yang diperlukan, sehingga dapat mencapai kompetensi yang ada.

2. Pemahaman Peserta Didik

Seorang guru harus memiliki kemampuan untuk memahami keadaan peserta didik. Sedikitnya terdapat empat hal yang harus dipahami guru dari peserta didiknya, yaitu tingkat kecerdasan, kreativitas, cacat fisik, dan perkembangan kognitif. Guru harus mampu mengetahui perkembangan psikologi anak, sehingga guru dapat mengetahui dengan tepat pendekatan yang dilakukan kepada anak didik. Setiap peserta didik memiliki kepribadian berbeda - beda, sehinga diharapkan seorang guru dapat membimbing anak untuk melewati masa sulit dalam usia yang dialami anak. Selain itu guru juga harus mengetahuan dan memahami latar belakang pribadi anak, agar guru dapat membantu dan memberikan solusi ketika anak memiliki masalah.

3. Merancangan dan Pelaksanaan

Pembelajaran

Merancangan dan pelaksanaan pembelajaran setidaknya menyangkut seorang guru harus mampu menyusun program pembelajaran yaitu RPP, komponen komponennya menyangkut kompetensi dasar, materi standar, metode atau teknik, media dan sumber belajar, serta waktu dan daya dukung lainnya. Setelah semuanya tersusun guru akan mengaplikasikan rancangan tersebut dalam pembelajaran.

4. Evaluasi Hasil Belajar

Evaluasi hasil belajar dilakukan untuk mengetahui perubahan perilaku dan pembentukan kompetensi peserta didik, yang dapat dilakukan dengan penilaian kelas, tes kemampuan dasar, dan penilaian akhir satuan pendidikan.

a) Penilaian Kelas

Penilaian kelas dilaksanakan dengan mengadakan ulangan harian. Dilakukan diakhir pembelajaran dalam satu bahasan atau kompetensi tertentu.

b) Tes Kemampuan Dasar Untuk mengetahui kemampuan membaca, menulis, berhitung yang diperlukan dalam rangka memperbaiki program pembelajaran.

c) Penilaian Akhir Satuan Pendidikan

Pada akhir semester dilakukan penilaian guna mendapatkan gambaran secara utuh dan menyeluruh mengenai 
ketuntasan belajar peserta didik, dalam satuan waktu.

5. Mengembangkan Potensi Anak Didik Pengembangan peserta didik harus dimiliki guru untuk mengaktualisasikan berbagai potensi yang dimiliki oleh peserta didik. Pengembangan peserta didik dapat dilakukan oleh guru melalui kegiatan ekstrakurikuler, pengayaan dan remidial, serta bimbingan dan konseling.

Berdasarkan pemaparan tersebut dapat disimpulkan bahwa kompetensi pedagogik adalah seperangkat penguasaan kemampuan yang harus ada dalam diri guru agar dapat mewujudkan kinerjanya secara tepat dan efektif. Guru perlu menguasai bahan pelajaran dan menguasai cara-cara mengajar, sebagai dasar kompetensi yang meliputi kemampaun: 1) Mengelola pembelajaran. 2) Pemahaman guru terhadap anak didik. 3) Perencanaan dan pelaksanaan pembelejaran. 4) Evaluasi hasil belajar. 5) Pengembangan anak didik untuk meningkatkan potensi yang dimilikinya.

\section{B. Kompetensi Profesional}

Menurut Soetjipto (1994) guru sebagai pendidik profesional mempunyai citra yang baik di masyarakat apabila dapat menunjukan kepada masyarakat bahwa ia layak menjadi panutan atau telada bagi masyarakat sekelilingnya. Masyarakat terutrama akan melihat bagaimana sikap dan perbuatan guru itu sehari hari, apakah memang ada yang patut diteladani atau tidak. Bagaimana guru meningkatkan pelayanannya, meningkatkan pengetahuannya, memberi arahan dan dorongan kepada anak didiknya, dan bagaimana cara guru berpakaian dan berbicara serta cara bergaul baik dengan siswa, teman - temannya serta anggota masyarakat, sering menjadi perhatian.

Hal yang berhubungan dengan keprofesionalan seorang guru adalah bagaimana pola tingkah laku guru dalam memahami, menghayati, dan mengamalkan sikap kemampuan dan sikap profesionalnya. Pola tingkah laku guru yang berhubungan dengan sikap keprofesionalan keguruan yaitu : Peraturan perundang - undangan, Organisasi profesi, teman sejawat, anak didik, tempat kerja, pemimpin, dan pekerjaan.

Kompetensi profesional merupakan kemampuan yang berkenaan dengan penguasaan materi pembelejaran bidang studi secara luas dan mendalam yang mencakup penguasaan substansi keilmuan yang menaungi materi kurikulum tersebut, serta menambah wawasan keilmuan sebagai seorang guru [4].

Guru profesional ditandai dengan pembelajaran di kelas yang efektif [1]. Adapun dimensi guru yang profesional dan efektif yaitu.

1. Pengetahuan Bidang Keilmuan

Seorang guru yang profesional menguasai meteri, struktur, konsep, dan pola pikir keilmuan yang mendukung mata pelajaran yang diampu.

2. Strategi Pembelajaran

Kemampuan yang harus dimiliki guru dalam melaksanakan proses belajar mengajar meliputi kemampuan : (1) menggunakan metode, model pembelajaran, media pelajaran, dan bahan latihan yang sesuai dengan tujuan pelajaran, mendemonstrasikan penguasaan mata pelajaran dan sarana prasarana pengajaran.

3. Pengetahuan Karakteristik Siswa Memahami dan dapat menerapkan teori belajar sesuai taraf perkembangan siswa. Mampu memberikan pujian atau respon positif kepada siswa pada setiap kesempatan dalam pembelajaran sehingga tercipta atmosfer yang menyenangkan di kelas.

4. Memanfaatkan teknologi informasi dan komunikasi untuk mengembangkan diri.

Memiliki kemampuan terkait bidang studi dengan memanfaatkan teknologi informasi dan komunikasi untuk mengembangkan pembelajaran yang relevan.

Berdasarkan pemaparan tersebut dapat disimpulkan bahwa kompetensi profesional berkaitan dengan bidang studi. Guru menjalankan tugasnya dalam pembelajaran tidak terbatas pada 
penyampaian informasi kepada peserta didik. Kemampuan guru yang bersifat khusus inilah disebut sebagai guru profesional ditandai dengan pembelajaran di kelas yang efektif meliputi pengetahuan bidang keilmuan, strategi pembelajaran di kelas, pengatahuan karakteristik siswa yang perlu dipegang oleh guru, dan guru itu sendiri bisa memanfaatkan teknologi informasi dan komunikasi untuk mengembangkan siswa dan diri sendiri guna keberhasilan pembelajaran.

\section{Motivasi Belajar Siswa}

Motivasi berasal dari kata motiv yang artinya sebagai daya upaya dalam diri yang mendorong sesorang untuk melakukan sesuatu. Motivasi dapat diartikan sebagai daya penggerak dari dalam dan dari dalam subjek untuk melakukan aktivitas tertentu demi menjacapai suatu tujuan. Motivasi juga dapet dikatakan sebagai rangkaian usaha untuk menyediakan kondisi - kondisi tertentu sehingga seseorang mau dan ingin melakukan sesuatu, ini berarti motivasi dirangsang oleh faktor luar tetapi motivasi itu tumbuh dalam diri seseorang [3]

Motivasi adalah dorongan dasar yang menggerakkan sesorang dalam bertigkah laku [5]. Dorongan ini berada pada diri seseorang yang menggerakkan untuk melakukan sesuatu sesuai dengan dorongan dalam dirinya. Motivasi menurut Suryabrata (2004) adalah keadaan yang terdapat dalam diri seseorang yang mendorong diri untuk melakukan aktivitas tertentu guna mencapai suatu tujuan. Selain itu motivasi adalah dorongan dasar yang menggerakkan seseorang dalam bertingkah laku. Dorongan ini berada pada seseorang yang menggerakkan untuk melakukan sesuatu yang sesuai dengan dorongan dalam dirinya.

Menurut candidasa mengatakan motivasi merupakan suatu keadaan intrinsik yang muncul, mengarah untuk memepertahankan prilaku motivasi menjadikan individu melakukan berbagai aktivitas seperti ; makan, belajar, bekerja, berbelanja, mengejar jabatan [6]. Menururt psikologi - psikologi yang telah memepelajari teori tentang motivasi, memutuskan terdapat tiga persoalan yang dihadapai ketika adanya motivasi, yaitu:
1. Persoalan hubungan pemicu suatu tindakan atau perilaku tertentu.

2. Persoalan hubungan keinginan seseorang untuk bergerak kesuatu tujuan tertentu.

3. Persoalan hubungan berkaitan dengan persistensi atau ketekunan seseorang dengan usaha dan tujuan tertentu.

Motivasi belajar timbul karena adanya minat dari dalam diri pesert didik. Minat dan keinginan berupa harapan - harapan masa depan yang lebih baik. Seorang peserta didik tentu memiliki harapan akan sebuah hasil belajar yang maksimal diakhir pembelajaran. Seseorang termotivasi untuk belajar karena melihat berbagai tanggung jawab sebagai seorang peserta didik. Seorang peserta didik akan sadar bahwa ia harus mandiri dan memenuhi tanggung jawabnya. Tanpa adanya motivasi peserta didik mungkin tidak akan dapat memenuhi kewajiban atau tanggung jawabnya sebagai peserta didik.

Berdasarkan pemaparan oleh para ahli, dapat disimpulkan motivasi merupakan daya penggerak atau kekuatan yang terdapat dalam diri seseorang untuk melakukan sesuatu guna mengarahkan pada tujuan yang hendak di capai, baik yang berasal dari dalam yang meliputi belajar karena ingin tahu, ingin berhasil, belajar merupakan kebutuhan, kegemaran, belajar demi masa depan, dan belajar dengan disiplin. Berasal dari luar yaitu belajar karena ingin dipuji, untuk mendapat nilai baik, dan diakui oleh teman.

Motivasi yang ada pada diri seseorang dalam melakukan suatu kegiatan dapat berbeda satu sama lain. Dalam melakukan suatu kegiatan seseorang bisa saja mepunyai motif lebih dari satu jenis. Karena itu motif dapat dibagi menjadi beberapa jenis. Di dalam literatur psikologi pembagian motif sebagai berikut [4].

1. Motivasi Intrinsik

Motif yang mendorong seseorang melakukan kegiatan tertentu, jadi motif ini terfokus didalam kegiatan atau objek yang ditekuninya. Siswa akan aktif dalam kegiatan belajar, karena adanya dorongan untuk mencari hal - hal berkaitan dengan 
pelajaran, dalam artian siswa akan menjadi lebih mandiri untuk belajar. Misal seorang siswa menekuni pelajaran tik, ia memang senang dan ingin menguasai pelajaran tersebut.

2. Motivasi Ekstreinsik

Motif yang mendorong seseorang melakukan kegiatan tertentu, tetapi motif tersebut terlepas atau tidak berhubungan langsung dengan kegiatan yang ditekuninya. Misalnya, seorang mahasiswa memasuki fakultas kedokteran hanya karena memenuhi keinginan orang tua. Sedangkan mahasiwa tersebut sebenarnya tidak berminat. Hal semacam ini bisa dikatakan dorongan untuk menyenangkan orang tua, sama halnya dengan ketika dikelas siswa terdorong atau termotivasi untuk menghindari hukuman guru, sehingga muncul dorongan untuk mendapat pujian dari guru. Dorongan mendapat nilai bagus, sehingga termotivasi untuk mendapat pengakuan atas dirinya dari teman teman sekelas.

Dari penjelasan tentang kedua motivasi tersebut, bahwa motivasi intrinsik itu jauh lebih baik daripada motif ekstrinsik, karena dengan motivasi intrinsik, seseorang akan belajar dengan inisiatif sendiri tanpa harus disuruh. Meskipun begitu motivasi ekstrinsik juga mempunyai manfaat yang tidak sedikit. Setidaknya dengan adanya motivasi tersebut seseorang tetap akan terdorong untuk belajar. Disamping itu seseorang yang terdorong belajar karena motivasi intrinsik, motivasi belajarnya akan bertambah kuat jika ia juga memiliki motivasi ekstrinsik. Hal yang perlu diwaspadai adalah jangan sampai seorang siswa tidak memiliki motivasi intrinsik sama sekali, sementara ia memiliki motivasi ekstrinsik yang banyak.

Berdasarkan pemaparan oleh para ahli, maka dimensi yang peneliti gunakan dalam penelitian instrumen motivasi adalah motivasi intrinsik dan motivasi ekstrinsik. Karena dimensi tersebut sudah mencakup dimensi motivasi secara keseluruhan.
Penelitian ini merupakan penelitian korelasi. Penelitian dilakukan dengan metode ex post facto (dilakukan untuk meneliti peristiwa yang telah terjadi secara sistematik, kemudian peneliti mengamati kebelakang tentang faktor - faktor yang dapat menyebabkan timbulnya kajian tersebut). Populasi dalam penelitian adalah seluruh siswa SMK se_Kota Singaraja. Sampel ditentukan melalui teknik random sampling dimana hanya siswa yang kelasnya pernah di ajar oleh guru PPL Jurusan Pendidikan Teknik Informatika.

Pengumpulan data dilakukan dengan menggunakan metode angket. Tujuannya untuk mengukur sejauh mana kompetensi pedagogik dan kompetensi profesional mempengaruhi motivasi belajar siswa. Data angket siswa kemudian dianalisis dengan melakukan uji prasyarat yang meliputi uji normalitas dan uji homogenitas. Pengujian hipotesis menggunakan uji anova.

Adapun tahapan-tahapan terhadap penelitian yang akan dilaksanakan untuk dapat mengungkapkan secara tuntas terkait permasalahan yang diajukan dalam penelitian ini adalah sebagai berikut.

1. Melakukan Observasi dan orientasi awal, yaitu menentukan sekolah yang akan dijadikan tempat penelitian dan melakukan pengamatan terkait rumusan masalah yang akan diteliti.

2. Menentukan populasi dan sampel penelitian dengan mencari kelas kelas pada tiap sekolah yang pernah di ajar oleh guru PPL Jurusan Pendidikan Teknik Informatikan, dengan teknik random sampling dari populasi sehingga akan ada 360 sampel dengan asumsi berasal dari siswa yang tersebar di SMK se-Kota.

3. Menyusun instrumen penelitian dan angket dengan dosen pembimbing dan uji ahli yang bersangkutan dan melakukan pengujian.

4. Uji Coba Instrumen. Pengujian instrumen dilakukan kepada siswa diluar populasi penelitian kemudian dilakukan uji validitas, uji reliabilitas.

5. Berdasarkan uji reliabilitas instrumen, peneliti kemudian engadakan pengambilan sesuai dengan sampel yang dimaksud dalam penelitian yaitu sebanyak 360 siswa.

\section{METODELOGI PENELITIAN}


6. Menganalisis data hasil penelitian untuk menguji apakah hipotesis yang telah diajukan diterima atau ditolak.

7. Melakukan Uji Hipotesis

8. Menarik kesimpulan berdasarkan hasil uji hipotesis

9. Membuat laporan

Uji normalitas dilakukan untuk mengetahui sebaran data siswa mengenai kompetensi pedagogic dan profesional guru PPL. Uji homogenitas dilakukan untuk mengetahui apakah varians kelompok siswa di masing - masing sekolah sama atau tidak, pengujian dilakukan dengan menggunakan uji F. Sedangkan uji hipotesis dilakukan untuk mengetahui apakah hipotesis alternatif yang telah diajukan diterima atau ditolak dengan menggunakan rumus anova.

\section{PEMBAHASAN}

Dari hasil pengukuran terhadap kompetensi pedagogik pada sampel yang berjumlah 360 siswa diperoleh nilai tertinggi adalah 56 dan nilai terendah adalah 14, banyak kelas interval 5 , dan panjang kelas interval adalah11,5. Rata-rata atau mean (M) kompetensi pedagogic sebesar 40,70. Analisis Deskriptif data kompetensi pedagogik dilihat pada Tabel 1.

Tabel 1. Analisis Deskriptif Data Kompetensi Pedagogik

\begin{tabular}{|c|c|c|c|}
\hline NNTERVAL & KATEGORI & FREKUENSI & $\begin{array}{c}\text { PERSENTASE } \\
\%\end{array}$ \\
\hline $45,50-<56,00$ & Sangat tinggi & 63 & 17,50 \\
\hline $38,50-<45,50$ & Tinggi & 155 & 43,06 \\
\hline $31,50-<38,50$ & Sedang & 98 & 27,22 \\
\hline $24,50-<31,50$ & Rendah & 44 & 12,22 \\
\hline $14,00-<24,50$ & Sangat Rendah & 0 & 0,00 \\
\hline
\end{tabular}

Kompetensi Pedagogik menunjukkan bahwa nilai kompetensi pedagogik yang sangat tinggi sebanyak 63 responden $(17,50 \%)$, kategori tinggi sebanyak 155 responden $(43,06 \%)$, kategori sedang sebanyak 98 responden $(27,22 \%)$, kategori rendah sebanyak 44 responden $(12,22)$ Tidak terdapat responden yang memiliki nilai dengan kategori sangat rendah.
Pada kompetensi profesional berjumlah 360 orang diperoleh nilai tertinggi adalah 36, dan nilai terendah adalah 9, banyak kelas interval 5 , dan panjang kelas interval 6,75. Rata-rata atau mean (M) komepetensi profesional sebesar 27,64. Analisis deskriptif data kompetensi profesional dapat dilihat pada Tabel 2.

Tabel 2. Analisis Deskriptif Data Kompetensi Profesional 


\begin{tabular}{|c|c|c|c|}
\hline INTERVAL & KATEGORI & FREKUENSI & $\begin{array}{c}\text { PERSENTASE } \\
\%\end{array}$ \\
\hline $29,25-<36,00$ & Sangat tinggi & 52 & 14,44 \\
\hline $24,75-<29,25$ & Tinggi & 296 & 82,22 \\
\hline $20,25-<24,75$ & Sedang & 11 & 3,06 \\
\hline $15,75-<20,25$ & Rendah & 1 & 0,28 \\
\hline $9,00-<15,75$ & Sangat Rendah & 0 & 0,00 \\
\hline
\end{tabular}

Dari tabel Analisis Deskriptif Data Kompetensi Profesional menunjukkan bahwa nilai kompetensi profesional yang sangat tinggi sebanyak 52 responden $(14,44 \%)$, kategori tinggi sebanyak 296 responden $(82,22 \%)$, kategori sedang sebanyak 11 responden (3,06\%), kategori rendah sebanyak 1 responden $(0,28)$ Tidak terdapat responden yang memiliki nilai dengan kategori sangat rendah.

Tabel 3. Uji Normalitas Data Penelitian

\begin{tabular}{|c|c|c|c|c|}
\hline Variabel & Mean & $\mathrm{SD}$ & $F_{\text {hitugg }}$ & $F_{\text {tabel }}$ \\
\hline $\begin{array}{c}\text { Kompetensi } \\
\text { Pedagogik }\end{array}$ & 40,07 & 6,44 & 0,019 & 0,072 \\
\hline $\begin{array}{c}\text { Kompetensi } \\
\text { Profesional }\end{array}$ & 27,64 & 1,98 & 0,022 & 0,072 \\
\hline
\end{tabular}

Berdasarkan hasil uji normalitas bila harga $F_{\text {hitung }}$ lebih kecil atau sama dengan $F_{\text {tabel }}\left(F_{\text {hitung }} \leq F_{\text {tabel }}\right)$, maka $\mathrm{H}_{0}$ diterima dan $\mathrm{H}_{\mathrm{a}}$ ditolak. $\mathrm{H}_{0}$ diterima berarti data berdistribusi normal. Pada kompetensi pedagogik nilai $F_{\text {hitung }}<F_{\text {tabel }}(0,019<$ 0,072 ). Pada kompetensi profesional nilai $F_{\text {hitung }}<\mathrm{F}_{\text {tabel }}(0,022<0,072)$ maka $\mathrm{H}_{0}$ ditolak atau $\mathrm{H}_{\mathrm{a}}$ diterima. Hal ini berarti data berdistribusi normal.

Uji homogenitas dilakukan dengan Uji Lavene, dari hasil perhitungan didapatkan nilai $F_{\text {hitung }}=21,689$. Kemudian nilai tersebut dibandingkan dengan nilai $\mathrm{F}_{\text {tabel }}=$ 2,219 ( $\mathrm{dk}$ pembilang $=5$, dk penyebut $=$ 1795, taraf signifikan 5\%). Harga $F_{\text {hitung }}$ lebih besar dari $F_{\text {tabel }}$ sehingga $\mathrm{H}_{0}$ diterima atau $\mathrm{H}_{a}$ ditolak maka sampel berasal dari populasi yang tidak homogen yang artinya data dari masing-masing kelompok mempunyai sifat atau varians yang tidak sama. Hasil tidak homogen bukan berarti penelitian ini salah melainkan dapat dipengaruhi beberapa faktor diantaranya : kecenderungan responden mengisi pernyataan pada angket kekurangan waktu, responden tidak terlalu ingat dengan subjek yang dituju atau dimaksud oleh pernyataan pada angket, dan adanya ketidak jujuran responden mengisi angket. Ketidakhomogenan ini tidak mempengaruhi penyelesaian analisis dengan statistik parametrik, karena dari hasil uji hipotesis ( uji T) yang peneliti lakukan menghasilkan hubungan yang terbukti kuat dalam hal ini hubungan yang positif dan signifikan antar variabel yang diteliti, meskipun data berasal dari data yang tidak homogeny. Hal ini di dukung oleh pernyataan " We may reasonably conclude that $F$ test, like $t$ test, is remark - ably robust. It is insensetive both to lack of normality in the populations and to differing population variance (unless these differences are extreme and are combined with marked differences in form). Because of this robustness it is, in fact, unusual for any check to be made on the normality of distribution unless the depature from normality in the groups sampled is seen to be extreme. Again, it is often unncessary to test for homogenity of variance. If however, an inspection of the score suggest a lack of homogenity-a pronounced diffrence in the 
group range, for instance-a test devised by Barttlet (1937) may be appliied "[7].

Berdasarkan hasil perhitungan uji hipotesis dengan anova menggunakan Microsoft Excel hubungan antara kompetensi pedagogik dengan motivasi belajar siswa dengan taraf signifikansi 5\% diperoleh $F_{\text {hitung }}=17,05$, dan $F_{\text {tabel }}=1,96$. Karena $F_{\text {hitung }}>F_{\text {tabel }}$ maka $\mathrm{HO}$ ditolak dan $\mathrm{Ha}$ diterima. Berdasarkan uji hipotesis dengan menggunakan anova menggunakan SPSS, nilai probabilitas signifikansi sebesar 0.000 , sehingga nilai signifikansi $0.000<0.05$ maka $\mathrm{HO}$ ditolak, dan $\mathrm{Ha}$ diterima. Hal ini menunjukkan bahwa terdapat pengaruh yang signifikan antara kompetensi pedagogic dengan motivasi belajar siswa.

Hubungan antara kompetensi profesional dengan motivasi belajar siswa dengan taraf signifikansi $5 \%$ diperoleh $F_{\text {hitung }}=10,81$, dan $F_{\text {tabel }}=1,96$. Karena $F_{\text {hitung }}>F_{\text {tabel }}$ maka $\mathrm{HO}$ ditolak dan $\mathrm{Ha}$ diterima. Berdasarkan uji hipotesis dengan menggunakan anova menggunakan SPSS, nilai probabilitas signifikansi sebesar 0.000 , sehingga nilai signifikansi $0.000<0.05$ maka $\mathrm{HO}$ ditolak, dan $\mathrm{Ha}$ diterima. Hal ini menunjukkan bahwa terdapat pengaruh yang signifikan antara kompetensi profesional dengan motivasi belajar siswa.

Hubungan antara kompetensi profesional dan profesional dengan motivasi belajar siswa dengan taraf signifikansi $5 \%$ diperoleh $F_{\text {hitung }}=123,84$, dan $F_{\text {tabel }}=3,87$. Karena $F_{\text {hitung }}>F_{\text {tabel }}$ maka $\mathrm{HO}$ ditolak dan $\mathrm{Ha}$ diterima. Berdasarkan uji hipotesis dengan menggunakan anova menggunakan SPSS, nilai probabilitas signifikansi sebesar 0.000 , sehingga nilai signifikansi $0.000<0.05$ maka $\mathrm{HO}$ ditolak, dan $\mathrm{Ha}$ diterima. Hal ini menunjukkan bahwa terdapat pengaruh yang signifikan antara kompetensi profesional dan profesional dengan motivasi belajar siswa.

Hubungan yang positif dan signifikan dengan koefisien determinasi sebesar 0,412 membuktikan bahwa motivasi belajar siswa yang dicapai sebesar $41,20 \%$ dapat dijelaskan berasal dari kompetensi pedagogik yang meliputi instrument (kemampuan mengelola pembelajaran, pemahaman peserta didik, dan perancangan pembelajaran), profesional (pengetahuan bidang keilmuan, strategi pembelajaran di kelas dan pengatahuan karakteristik siswa). Sedangkan 58,80\% lainnya ditentukan oleh variabel lain yang tidak diteliti memiliki pengaruh yang lebih besar terhadap motivasi belajar siswa.

Populasi bukan sekedar jumlah yang ada pada objek/subyek yang dipelajari tetapi meliputi seluruh karakteristik/sifat yang dimiliki oleh subyek atau obyek itu. Jika dilihat dari jumlah responden, 360 siswa memiliki karakteristik yang berbedabeda. Ada beberapa siswa yang cenderung tidak memperhatikan butir instrumen dengan teliti. Jumlah responden yang banyak, kurangnya perhatian siswa sebagai responden dan waktu pengisian angket yang terlalu cepat juga dapat meyebabkan faktor lainnya yang tidak diteliti memiliki pengaruh yang lebih besar terhadap motivasi belajar siswa [8].

Hal ini membuktikan bahwa tidak hanya kompetensi pedagogik dan profesional yang mempengaruhi motivasi belajar siswa, namun ada variabel lain yang peneliti tidak kaji dalam penelitian ini juga berpengaruh terhadap motivasi belajar siswa. Mengiingat bahwa kompetensi dasar yang dimiliki oleh soorang guru ada 4 (empat) kompetensi yaitu kompetensi pedagogic, professional, personal, dan sosial. Selain itu variabel lain yang dapat mempengaruhi motivasi belajar siswa selain variabel kompetensi yang di bahas. Pengaruh orang tua sangat berperan penting dalam memotivasi belajar siswa. Berdasarkan uji stastistik korelasi product moment diperoleh nilai $r$ sebesar 0,47 yang berarti terdapat hubungan yang sedang antara perhatian orang tua di rumah dengan motivasi belajar siswa. Hubungan ini bersifat positif, yang berarti semakin baik perhatian orang tua di rumah pada anak semakin baik pula motivasi belajar anak. Sedangkan $\rho$ value sebesar $0,025<0,05$, berarti terdapat hubungan yang singnifikan antara perhatian orang tua terhadap motivasi belajar siswa [9]. Fasilitas belajar dan lingkungan belajar secara simultan berpengaruh positif terhadap motivasi belajar siswa program keahlian APK di 
SMK Taruna Jaya Gresik dengan nilai signifikansi kurang dari $0,05(0,000<0,05)$ [10].

Kualitas instrumen dan kesalahan pengambilan sampel, kesimpulan hasil penelitian bisa salah jika instrumen yang digunakan kurang tepat (valid) untuk mengukur variabel/objek yang diteliti. Kesimpulan hasil juga bisa salah jika subjek mengisi instrumen tidak sesuai sasaran, bisa jadi subjek penelitian mungkin sudah sesuai sasaran, tetapi tidak jujur dalam mengisi data yang diperlukan sehingga hal itu juga mengakibatkan varian jawaban siswa tidak sesuai harapan (Endang Mulyatiningsih, 2015).

Adapun kendala yang dialami dari penelitian ini adalah keberhasilan belajar siswa tidak hanya dipengaruhi oleh kompetensi yang dimiliki oleh guru PPL, peran siswa, orang tua, sekolah, dan Jurusan Pendidikan Teknik Informatika untuk dapat meningkatkan/ mengoptimalkan pelaksanaan PPL-Real.

Waktu pelaksanaan penelitian agar pengambilan data tidak terlalu memiliki jarak seperti yang peneliti lakukan, walaupun penelitian ini bersifat expost facto. Hal ini sangat berpengaruh terhadap responden karena ketika pengumpulan data responden tidak mengingat dengan baik objek ataupun subjek yang kita maksud pada penelitian. Sehingga terjadi beberapa hal - hal yang tidak diinginkan seperti kecendrungan responden mengisi data tidak jujur. Ketidakjujuran ini juga timbul karena kurangnya pemahaman responden terhadap tujuan pengambilan data misal responden tidak leluasa mengisi data karena asumsi responden (siswa) data yang diberikan akan diakumulasi dengan nilai mereka disekolah.

Penelitian ini hanya membahas 2 (dua) variabel yaitu kompetensi pedagogik dan profesional sebagai kompetensi dasar yang dimiliki oleh guru. Selain kompetensi pedagogik dan profesional terdapat kompetensi lain yang juga mempengaruhi motivasi belajar siswa, kompetensi personal dan sosial juga mempengaruhi motivasi belajar siswa, dari hasil penelitian di dapat masih banyak faktor/ variabel yang dapat memepengaruhi motivasi belajar siswa. Variabel lain yang dapat mempengaruhi motivasi belajar siswa misalnya dukungan orang tua, lingkungan, fasilitas belajar (sarana prasarana).

Berdasarkan hasil yang diperoleh, penelitian ini secara umum telah mampu menjawab dan menemukan faktor/ variabel lain yang mempengaruhi motivasi belajar siswa yang tidak dijelaskan dalam penelitian ini.

\section{SIMPULAN}

Berdasarkan paparan hasil penelitian, dan pembahasan dapat disimpulkan sebagai berikut.

1. Terdapat hubungan yang positif dan signifikan antara kompetensi pedagogik terhadap motivasi belajar siswa (Y). Hal ini ditunjukkan oleh koefisien korelasi sebesar 0,67 artinya jika semakin baik nilai kompetensi pedagogik guru PPL, maka akan meningkatkan motivasi belajar siswa, begitu pula sebaliknya. Tingkat hubungan antara keduanya kuat. Koefisien determinasi sebesar 0,45 menyatakan bahwa variabel kompetensi pedagogik hanya memberikan sumbangan sebesar $44,82 \%$ terhadap motivasi belajar siswa

2. Terdapat hubungan yang positif dan signifikan antara kompetensi profesional terhadap motivasi belajar siswa (Y). Hal ini ditunjukkan oleh koefisien korelasi sebesar 0,50, artinya jika semakin baik nilai kompetensi profesional guru PPL, maka akan meningkatkan motivasi belajar siswa, begitu pula sebaliknya. Tingkat hubungan antara keduanya sedang. Koefisien determinasi sebesar 0,25 menyatakan bahwa variabel kompetensi profesional hanya memberikan sumbangan sebesar $24,62 \%$ terhadap motivasi belajar siswa.

3. Terdapat hubungan yang positif dan signifikan secara bersama sama kompetensi pedagogik dan profesional terhadap motivasi belajar siswa $(Y)$. Hal ini ditunjukkan oleh koefisien korelasi sebesar 0,64, artinya jika semakin baik nilai kompetensi pedagogik dan 
profesional guru PPL, maka akan meningkatkan motivasi belajar siswa, begitu pula sebaliknya. Tingkat hubungan antara keduanya sedang. Koefisien determinasi sebesar 0,25 menyatakan bahwa variabel kompetensi profesional hanya memberikan sumbangan sebesar $41,20 \%$ terhadap motivasi belajar siswa.

\section{REFERENSI}

[1] Wahyudi, I. (2012). Imam Wahyudi (2012) 2012. Pengembangan pendidikan stategi inovatif dan kreatif secara komprehensif.Jakarta: Prestasi pustaka.

[2] Undiksha. (2007). Petunjuk Praktis pelaksanaan PPL-Real. Singraja: Undiksha.

[3] Sardiman., S. (2005). Interakti dan Motivasi Belajar

[4] Hakim, T. (2000). Belajar Secara Efektif. Jakarta: Puspa Swara.

[5] B.Uno, H. (2008). Landasan Manajemen Pendidikan. Bandung : Rosdakarya.

[6] Candiasa, I. M. (2007). Pengujian Instrumen Penelitian Disertai Aplikasi ITEAM dan BIGSTEPS. : . Singaraja: Unit Penerbitan Universitas Pendidikan Ganesha.

[7] Lewis. (1968). Experimental design in education. London: London university of London press LTD.

[8] Sugiyono. (2013). Metode Penelitian Kuantitatif Kualitatif Dan $R$ \& $D$. Bandung: Alfabeta.

[9] Noviana. (2014). Pengaruh Fasilitas Belajar Dan Lingkungan Belajar Terhadap Motivasi Belajar Siswa Program Keahlian Apk Di Smk Taruna Jaya Gresik. Fakultas Ekonomi, Unesa, Kampus Ketintang Surabaya, 22-23.

[10] Febriany, R. Hubungan Perhatian Orangtua Dengan Motivasi. Jurnal IImiah Konseling, 8 - 16. Diambil kembali dari http://ejournal.unp.ac.id/index.php/kon selor/article/viewFile/727/597 